\title{
USE OF INFORMATION
}

\section{AND COMMUNICATION TECHNOLOGIES \\ IN OFFICIAL WEBSITES OF GMINAS.}

\author{
ARE THE POLISH RURAL AND URBAN-RURAL LOCAL \\ GOVERNMENTS PREPARED TO COMMUNICATE WITH THE \\ YOUNGER GENERATION - DIGITAL NATIVES, GENERATION Y?
}

\author{
Krzysztof Kowalik ${ }^{1}$ \\ PhD, Assistant Professor of the Faculty of Journalism, \\ Information and Book Studies of the University of Warsaw, \\ Address: University of Warsaw, 26/28 Krakowskie Przedmieście, \\ 00-927 Warsaw, Poland. \\ E-mail: k.kowalik7@uw.edu.pl; kowalik.it
}

\begin{abstract}
The article takes a close look at the very current subject of online communication using modern and popular channels of interaction that can help build «small motherlands», particularly among young web ${ }^{2}$ users. The author focuses on the rarely addressed topic of using ICT in rural and urban-rural gminas ${ }^{3}$ to deal with the environment of local government, especially with the generation of «digital natives», the countryside "generation Y». In the article the communication preference of the named generations is indicated and the results of the tests for official services of gminas and profiles carried out by local authorities in the popular social networking site are presented. The author compares data obtained in different periods of research, which allows for the determination of trends in the use of tools of communication of the rural and urban-rural offices with young people.
\end{abstract}

Keywords: Internet; rural and urban-rural areas; local government communication; young generation.

\footnotetext{
1 Krzysztof Kowalik belongs to the editing team The Journalism Research Review Quarterly. His main research fields are local government media, communication between citizens and local authorities, using IT tools in management of community (rural, urban - rural and urban areas, big cities). He is interested in media education of young people.

2 The term "web" will be used in the text as synonymous to "the Internet".

${ }^{3}$ Gmina - the principal unit of the local government in Poland, similar to a municipality or a council in English (in the article the Polish term is used to avoid misunderstanding).
} 
Citation: Kowalik, K. (2019). Use of Information and Communication Technologies in Official Websites of Gminas. Are the Polish Rural and Urban-Rural Local Governments Prepared to Communicate with the Younger Generation - Digital Natives, Generation Y? Public Administration Issue, Special Issue I (electronic edition), pp. 140-154 (in English); DOI: 10.17323/1999-5431-2019-0-5-140-154.

\footnotetext{
C
} ommunication and information have always been an important element influencing or even performing social changes by changing the dominant forces or those in power. In an industrial society, information was conveyed by mass media, i.e. traditional media (newspapers, radio, television) which are one-sided (one to many). However, the basis of modern communication in a network society has become a horizontal communication with the use of the global network (many to many) (Castells, 2007). Broadly-understood, an authority which organizes or manages the community should adapt to changes in order to effectively communicate with the environment, in particular the communities building their «small motherlands». Modern communication, message content and interactions are related to technologies that are used in the computer network.

\section{The range of network communication in rural areas}

In Poland, the areas where there is no access to the internet have been greatly reduced and the number of people who cannot use it is decreasing. In 2015, 71\% of households had the ability to communicate online, in families with children this percentage increases to $95 \%$. Only $5 \%$ of households cannot afford access to the internet (Diagnoza Społeczna (Social Diagnosis), 2015, pp. 357). Also the structure of the equipment is changing as laptops have become more prevalent; every fourth household has at least one tablet and this is a growing trend. The popularity of mobile internet is also increasing, which is associated with the increasing number of smartphones $-45 \%$ of Poles aged 16 or older have this kind of device (Diagnoza, pp. 356, 360) while $27 \%$ of internet users, mostly young people (17.5\% of the population), reported the use of data transfer in their smartphones and tablets. Still visible are the differences in access to the network in rural areas $-67.5 \%$ of households can connect online (while $57.3 \%$ use the network), whereas the average for cities is $74.7 \%(72.7 \%)$ (Diagnoza, pp. 360, 361, 367). The data on the mobile Web varies as well - the number of users in the countryside is $11.6 \%$, in cities the average is $22.5 \%$. It is worth pointing out that there is a growing percentage of mobile internet users in groups of young people. In the age group 16-24 years mobile internet is used by $97.5 \%$ of them, in the group aged $25-34$ - by $92.9 \%$, and in the group aged 35-44 the percentage is $85.6 \%$. They also spend the most time online (Diagnoza, pp. 367-368, 374).

\section{ICT and (new) public governance}

The main goal of public governance is to manage effectively using all the available resources in a democratic environment. It is important especially for local governments to implement community goals as well as the needs of society, organizations and private companies. All of these form a network of regional connections 
of common or divergent sector interests. Cross-sectoral integration and networking are necessary factors to balance local social and economic development. The key issue is to be able to identify and predict all regional needs and rising conflicts and to work out together the best solution for community. Nowadays, public administration implements various levels of interaction, for instance using ICT «as a tool to achieve better government»(OECD, 2003) and changing traditional administration into one of an e-government type (Pollitt, Bouckaert, 2011). The adoption of new technologies improves environment-government communication, speeding up feedback. Procedures in public governance are more transparent and the structure of the government (local institutions also) becomes more socially responsible, more open to forming "partnerships between different public sector bodies which link different types of services» (McQuaid, 2010, pp. 125-146).

Public sector openness and new ways of accountability can become essential factors in increasing citizens' trust in good governance (Demchak at al., 2000, pp. 179-196). Social participation means the active engagement of citizens in decision-making, but authorities should give access to information. As the government seeks to involve the community and advance public services, it must share information by the same, most popular, communication channels like citizens do. Primarily all governmental organizations should «be where the people are!» (Mergel, 2010, pp. 7-10). Nowadays, one of the most effective, interactive tools is social media - the net of networked people. Network platforms offer more communication possibilities and more interactivity. Public service delivery may be based on the network, multiple interdependent actors and multiple processes informing the policy-making system and forming New Public Governance (Osborne, 2006, pp. 377-387). A new concept or a perspective in fact is short-lived and the NPG «it is neither that normative nor that prescriptive» (Osborne, 2010, p. 1) may be considered as «hybrid governance» (Dickinson, 2016, pp. 41-46). Government authorities, and local communities also, should understand the main communication trends, like the increasing potential of ICT and first of all the key factor - activity, or better to say, interactivity of the younger generation in social media. It could help to persuade them to cooperate, to engage in community affairs, thus unleashing the potential of the young community, creating solutions for the future.

\section{«Digital natives», «generation Y» - communication habits}

The message content should be adapted to the competence of the recipients, their habits and the communication tools they use every day. This is important especially if the message has to reach out to groups for which there are no technological barriers to movement on the web. This generation, which Marc Prensky called the generation of «digital natives» (Prensky, 2001), freely uses the tools of not just modern communication, but interaction. The internet is their integrated environment. If the message for this group is prepared by «digital immigrants» (who do not always deal with technologies), it may not bring the expected effect. In the literature there is another established term for a generation which freely uses the communication technology - «millennials». Neil Howe and William Straus in the book «Millennials Rising: The Next Great Generation» de- 
scribe a generation devoted to new technologies as eco-friendly and the global network as reliable. They recognize «millennials» as a generation preferring cooperation, forming social networks and freely using internet tools, which affects, among other things, economics and politics (Howe, Strauss, 2000, p. 315).

This generation, also known as "generation Y» (Howe, Strauss, p. 6; Advertising Age, 1999), are people born after 1980 (there are discrepancies in determining that date, Wrzesień, 2007, pp. 135; Mysior, 2014, p. 5), perfectly explored the Web 2.0 environment, and using the Google search engine (hence as well "generation Web 2.0", "generation Google": Wawer, 2013, p. 164). These skills should draw the attention of internet communication managers as it becomes necessary to consider the preferences of the generation «born with the computer», treating technologies «like air» (Tapscott, 2009, p. 18).

«Generation Y» commonly uses website communication, in particular that based on the philosophy of Web 2.0 activities. This was characterized by O'Reilly (2009) who pointed out its key elements which are: cooperation, participation and interaction. These tools and communication channels include social networking sites, blogs and RSS feeds (O'Reilly, 2009). In carrying out communication with the environment, social networking sites should not be undervalued. According to institutions tracking trends in social media, in Poland there are 15 million active users of social networking sites (an annual increase of 7\%), out of which 12 million use mobile devices (an increase of 20\%). The use of laptops, desktop computers and tablets is decreasing (a drop of 12\% for laptops and desktop computers, and $10 \%$ for tablets), while it is rising in phones (an increase of $12 \%$ ) [Wearesocial.com]. The most popular social networking platforms in Poland are YouTube (69\% of users reported using the site), Facebook (62\%), Google Plus (39\%), FB Messenger (32\%), Skype (25\%), Twitter (24\%), Instagram (24\%), Nasza Klasa (Our Class; 19\%), WhatsApp (16\%), Linkedin (13\%), Pinterest (13\%), and Snapchat (13\%) [Wearesocial.com]. In 2016 in Poland, the portal Facebook.com alone was used by 15.5 million people (in the 13 to $50+$ age bracket), out of which were 2.5 million in the 13-18 age bracket, 3.5 million in the 19-25 age bracket and 3.3 million in the 26-33 age bracket (Lien, 2017). Out of all these users, $80 \%$ use mobile access, and $73 \%$ visit the portal daily. The gap between generations increases. Parents - i.e. «millenials» - know less and less about the next generation of communication - i.e. their children (Kowalik, 2015).

\section{The local information and communication needs of public institutions}

Internet services of the local government provide an opportunity for it to conduct its own information policy directed not only to the local community, but also to the environment of the gmina in the broader sense, for example Public Relations activity (Kowalik, 2018, pp. 51-63). Statistics prove that internet users are interested in local information. According to the organization Polskie Badania Internetu (PBI), which measures Polish internet audiences, services related to the region at least once a month are visited by over 16 million people. What is important is that 11.3 million use computer access and 9.9 million use mobile devices, generating 500 million page views per month. It is worth noting that $35 \%$ of the 
users are inhabitants of rural areas. A significant proportion are young users - 17\% in the 15 to 24 age bracket and 25\% aged 25-34 (PBI, 2016, pp. 13-14, 19, 21). The study was focused on commercial web services but the numbers indicate the needs of internet users. Administrators of local services can use it to attract «generation $Y$ » to their social network. Young users will use the modern, often automated and personalized communication tools and Web search engines, which may increase the chances of local government services to have a more significant role in network communication.

Internet users using the services of public institutions are looking for a wide range of information. Most users' interests include matters concerning the everyday functioning of the office and the possibility of taking care of a specific issue, becoming familiar with the information in Biuletyn Informacji Publicznej (Bulletin of Public Information), data and reports, but also presenting the opinion, consultations, discussions and polls, and making appointments in the office (E-administracja w oczach internautów, 2016, pp. 15-16; the directory is broader, but not included with the latest e-administration studies - cf. E-administracja w oczach internautów, 2013, p. 32).

Today websites are considered the standard medium used by commercial and non-commercial organisations. However, not all of them have official websites and the information is published on the pages of the BIP. During the study among rural gminas there were 11 of such local governments (388 surveyed); all the urbanrural gminas had their own websites.

Local governments as public institutions should apply the principle of legalism when creating their media. In accordance with the relevant decisions of the courts ${ }^{4}$, websites are regulated by press law ${ }^{5}$. Hence some of the gminas treat official sites as the titles of press releases and register them in the district courts ${ }^{6}$. From the author's research it appears that 5\% of rural gminas and $6.3 \%$ of the urban-rural ones reported their websites as the titles of press releases ${ }^{7}$. Despite the judicial registration, there is no information on the official pages resulting from the laws in force (Article 27 of the press law), such as: name and address of the publisher, name of the editor in chief, or international information sign.

\section{Data and methodology}

The aim of the study was to diagnose the ICT used by local governments to communicate online, especially in interaction adapted to «generation Y». To confront the needs of internet users and communication channels that are feasible to use, the

\footnotetext{
${ }^{4}$ See the written justification for the judgment of the court concerning the registration of the site of the local government authorities: judgment on behalf of the Republic of Poland, Case Number: C 1045/13. Available at: http://orzeczenia.lublin.so.gov.pl/content/\$N/153005000000503_I_C_001045_2013_Uz_2014-02-24_001 (accessed: 27 December, 2014).

5 Article 45 of Press Law Act of 26 January 1984 (Dz.U. of 1984, Number 5, item 24), as amended.

6 In accordance with Article 20, paragraph 1 of the Press Law Act (cf. footnote 21) publishing of a journal or a magazine requires registration in the county court of competent jurisdiction for the registered office of the publisher.

7 On the basis of a survey carried out in October 2014. Questionnaires were e-mailed to all local governments; the return rate was $9.5 \%$.
} 
appropriate network tools were chosen, which may be used by local authorities for the purposes of establishing interaction with the environment (Table 1).

Table 1

\section{Assigning online tools for the communication needs of internet users}

\begin{tabular}{|l|l|}
\hline \multicolumn{1}{|c|}{ Needs of internet users } & \multicolumn{1}{|c|}{ Online communication } \\
\hline The functioning of the office, contact details, reports & $\begin{array}{l}\text { The department of information (news), } \\
\text { RSS, newsletters }\end{array}$ \\
\hline Submitting opinions, consultations, discussions and polls & Discussion forums, social networking sites \\
\hline
\end{tabular}

The hypothesis assumes that local governments, regardless of their status (rural and urban-rural gminas - categorization is assigned by administrative division of the country), adapt their online communication to the habits of the "digital natives» by introducing new ICT tools and Web 2.0 channels. The main research questions were:

- What tools are preferred in which local governments (rural or urban-rural)?

- What changes occurred between the periods of research - trends?

- What is the role of Web 2.0 tools in communication?

The data shown in the article are based on the results of tests carried out by the author in the period 2014-17. The results allow you to compare the selected results and diagnose many aspects of online communication development in urban-rural and rural gminas. The author used the results of observation of the official local government websites in two periods - May 2016 and April 2017. In both research periods the same group of urban-rural and rural government services was checked. Using the address database of Local Government Units of the then Ministry of Administration and Digitization (Pol. Ministerstwo Administracji i Cyfryzacji) 25\% of local governments were selected from each voivodeship (out of 1559 rural and 616 urban-rural gminas). The data allows for indication of the dynamics in changes of tools which are used in communicating with the environment. In the second period, research was focused on analyzing the differences in the use of communication tools of Web 2.0. An online survey conducted in October 2014 was also used in the article; the persons responsible in gminas for official media were to respond to questions about the role of online interaction and the use of the internet as a new distribution channel for content published by local governments. In February 2017, three profiles of rural and three of urban-rural gminas were under observation on the portal Facebook.com. Local governments were identified based on observation (25\% of gminas from each voivodeship) of the official gmina offices websites. Their presence was checked on Facebook.com, and on the basis of the number of people who "liked» the page, local governments with the lowest, highest and average number were selected, and calculated separately for rural and urban-rural gminas. The average was measured by dividing the number of inhabitants (data from GUS Central Statistical Office of Poland 2015) by the number of people who "liked" the gmina's profile. It should be noted that the indicator was used due to the lack of other quantitative correlation (or another selection criterion) which could appear before 
the copyright examination between users who "liked» profiles of local governments and the activity of gminas on the portal Facebook.com. In the social networking service both the owners' and users' activity was observed. For four weeks the activity of profile owners and of people who found them interesting was analyzed statistically. An attempt was made to diagnose the content which can affect the activity of people interested in local government policy. Official profiles on Facebook.com do not inform about the age structure of the recipient.

\section{Test results}

In the review of both the rural and urban-rural sites, you can see that their structure and communication tools used are similar to sites created by media professionals. Bookmarks informing you about current events are one such element. Called news or events, the latest news appears on the welcome page of the sites; more rarely they are located deeper in the structure of the site, for example, in the mandatory BIP, where finding them requires thorough searching of local government online resources.

The main task of the media is to inform. Referring to communication trends, local governments align their Web services to the requirements of the users, especially those using modern technologies. Some local websites publish not only local news, but also information coming from national or worldwide services. Also included are currency exchange rates, the lottery results or stock quotes. The layout of the sites refers to information portals or even television news outlets, because links are displayed in the form of a horizontal bar (as an active link to online sources) as it moves across the screen.

Most of the local governments focus their sites on regional news. In 2016, $94.8 \%$ of rural gminas had a section which informed its readers about current events; in the following year this percentage slightly increased to $96.6 \%$. For the local communities, one of the most important pieces of current information was the access to knowledge about the government Rodzina 500 Plus (Family 500 Plus) ${ }^{8}$ project, for which formalities had to be taken care of in the gmina office. In the course of the observation of the local government sites, it was being tested, which for them added a permanent element to the site by publishing data on the submission of applications. Three weeks after coming into force, the program was significantly amending the financial situation of many families. In 2016, 41.8\% of sites had a permanent link identifying the prerequisites for the aid.

A year later, a halving (from $41.8 \%$ to $20.1 \%$ ) in the number of rural sites with information about Rodzina 500 Plus, was noted.

The situation is similar in urban-rural gminas. In 2017, the number of sites with a current news section increased by almost $10 \%$ (from 89.6 to $99.4 \%$ ). As in the case of local rural services, the number of links to the details regarding Rodzina 500 Plus decreased (from $46.6 \%$ in 2016 to 28.8 in 2017).

The internet network, thanks to the used technology and tools, allows individuals to quickly publish content. Distribution providing your message with instant reach

\footnotetext{
8 More broadly in: Zasady i warunki Programu 500 plus (Terms and conditions of the Program 500 plus). Available at: http://www.program500plus.pl/ (accessed: 1 December, 2016).
} 
to the recipient is also necessary. Gmina services, in adjusting their channels of communications, should take into account the use of common tools, such as RSS feeds and newsletters. The research showed that the number of local governments using RSS slightly increased, while the number of websites enabling individuals to sign up to receive automatically sent emails dropped by nearly one-third (see Chart 1).

A similar thing occurred in urban-rural gminas (see Figure 1). The increase in the number of sites with RSS channels is higher, but the decline in the prevalence of newsletters is at a similar level as in rural areas.

\section{Figure 1: Rural and urban-rural gminas - RSS and newsletters in services (as a percentage)}

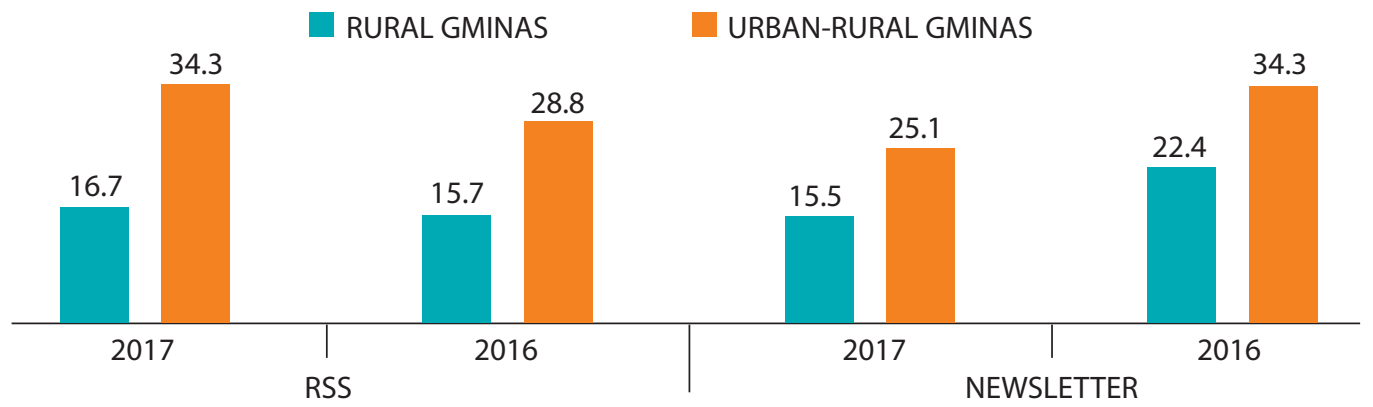

Source: Here and below in the Figures - author's research.

Among young internet users, social networking sites are popular channels of not only communication but also interaction («liking», «sharing», commenting). In rural gminas, the interest in these types of portals is much smaller - in 2016, $26.8 \%$ of local authorities published links to their profile on Facebook.com (see Chart 5), whereas among urban-rural ones $41.7 \%$ had a profile (see Chart 6). The increment in the number of profiles in the next year is much greater in urbanrural units. In both types of local governments there is a significant increase in the interest in the community related to videos that are on YouTube.com. Services such as Google Plus, Twitter and Instagram have far less followers (cf. Figures 2 and 3).

\section{Figure 2: Rural gminas - social networking on the gmina sites (in percentages)}

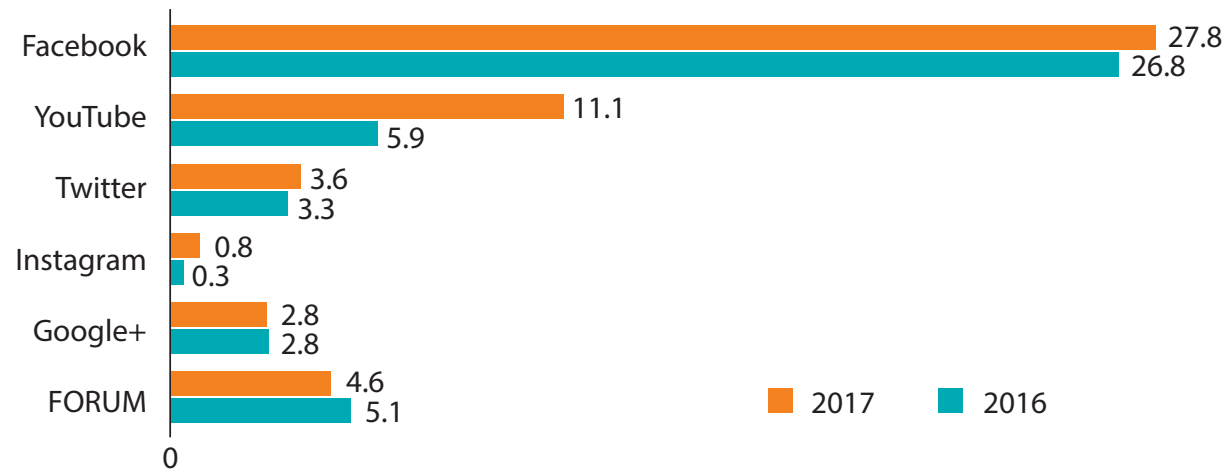




\section{Figure 3: Urban-rural gminas - social networking on the gmina sites} (in percentages)

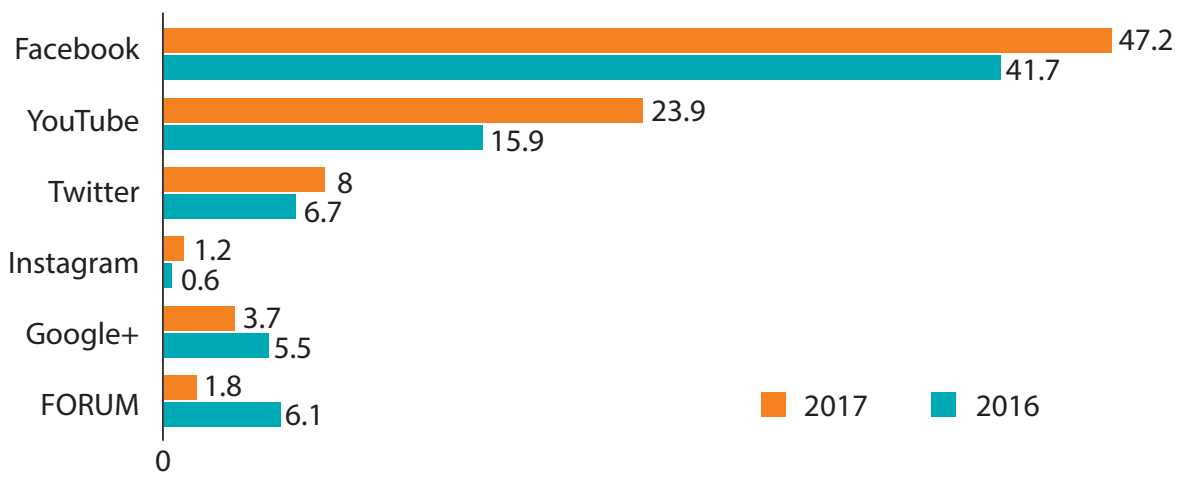

The research showed that in the last three years the approach of local authorities in order to communicate with the environment with the use of social networking sites had considerably changed. In 2014, 74\% of representatives of rural gminas and $34 \%$ of urban-rural gminas commented negatively on local governments having profiles on Facebook, Twitter, etc.. ${ }^{9}$ In 30\% of responses from rural gminas the message was that «no profiles are needed for local governments» (see Figure 4). A similar opinion was found in urban-rural gminas, but its percentage was much lower (17\%). Opinions about «lack of interest from the local community» and the «existing unofficial profiles of local governments» were quite surprising.

\section{Figure 4: Rural and urban-rural gminas - opinions on the presence on social networks (in percentages)}

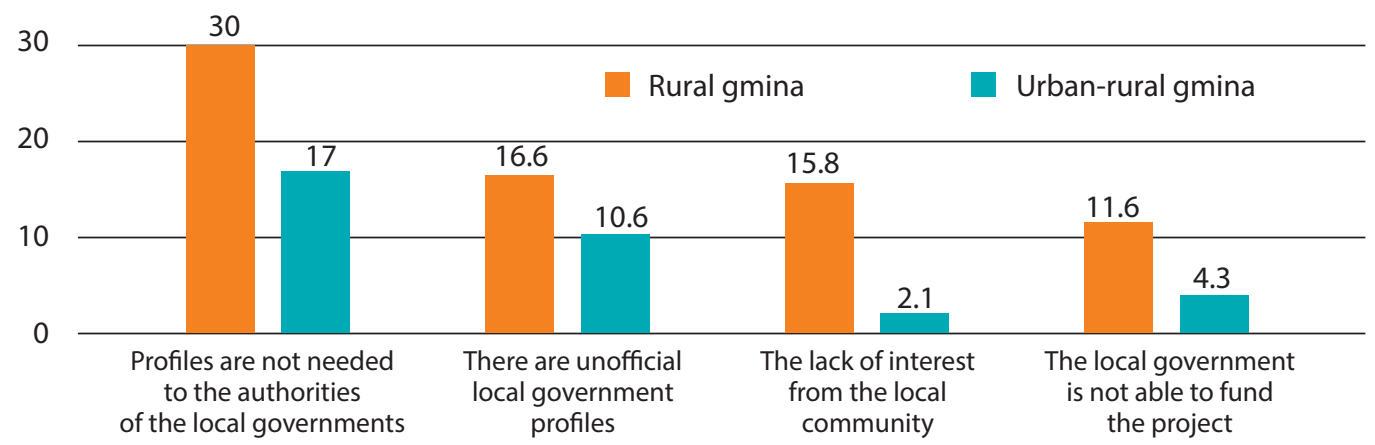

The financial aspect was also noted in the surveys - «the local government is not able to fund the project», probably due to the shortages of human resources prepared to conduct effective communication using social profiles. The results of the research indicate that tools such as discussion forums are in a phase of decline in both rural and urban-rural gminas. Especially in urban-rural gminas, a decrease in the number of forums is significant (see Chart 2 and Chart 3). Out of the tested sites, only one showed activity, which was proven by the number

\footnotetext{
9 The results of the author's research. In 2014 a website survey was carried out; it was addressed to all local governments in Poland. The rate of return was 9.5\%.
} 
of published posts and threads ${ }^{10}$. Other local government forums were inactive or they were only links directing to empty sites. The situation is similar in the case of rural gminas where there are non-functioning links ${ }^{11}$ or confusion in their name ${ }^{12}$. There are also forums showing their last entries dated $2012^{13}$.

Study results on local government communication with the use of social networking sites differ markedly according to their activity and the type of published content. In order to observe gminas an indicator was searched for so as to diagnose local government communication. For the study, the official profiles with the highest, the smallest and the average number of «likes» for a given type of gmina were chosen (arithmetically, the higher the number was, the less inhabitants «liked» a profile - author's note, see Table 2).

Table 2

\section{The values of the indicator for gminas}

\begin{tabular}{|c|l|c|c|}
\hline \multicolumn{2}{|c|}{ Services of urban-rural gminas } & \multicolumn{2}{|c|}{ Services of rural gminas } \\
\hline 4.58 & Kargowa & 5.74 & Bobrowo \\
\hline 9.37 & Bystrzyca Kłodzka & 10.83 & Babice \\
\hline 15.18 & Grodzisk Wlkp. & 24.49 & Dąbrowa Zielona \\
\hline
\end{tabular}

Source: Author's research

Results of observation of the official profiles show a surprising regularity concerning the response to the posts. Gminas with the highest rate (that is, few inhabitants liked the profile) published more posts. Also the interaction was greater as is indicated by the number of «likes» given to the posts, published comments, and shares (see Figure 5).

\section{Figure 5: Rural and urban-rural gminas - comparison of the number of posts and response to them (in numbers)}

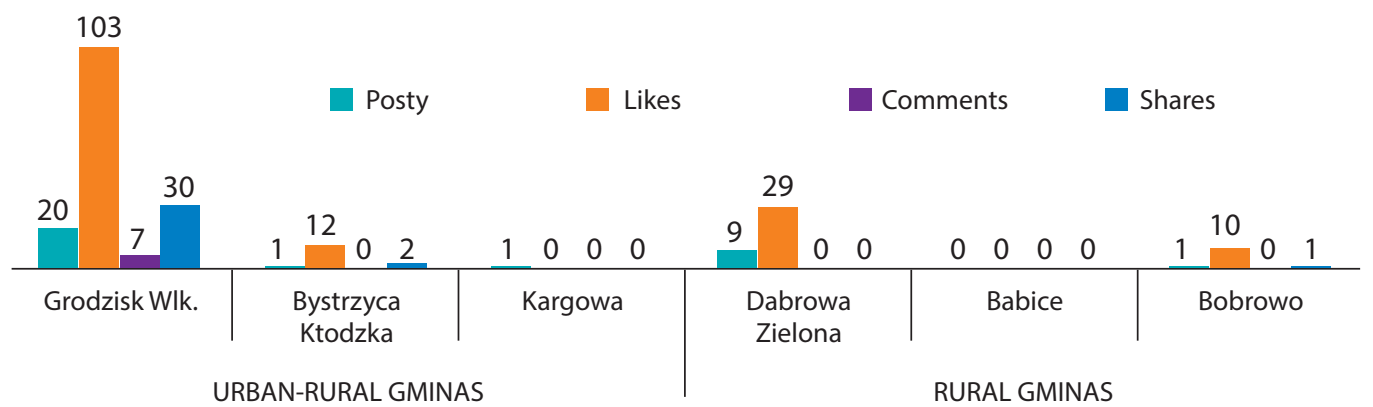

\footnotetext{
${ }^{10}$ See forum of urban-rural Błonie gmina [online]. Available at: http://www.um.blonie.pl/forum/ (accessed: 1 May, 2016).

${ }^{11}$ See the link to INTERNETOWE FORUM GMINNE gminy Adamów (discussion forum of Adamów gmina) [online]. Available at: http://adamow.forumgminne.pl/ (accessed: 1 May, 2016).

12 See the link to the guest book of Bełżec gmina [online]. Available at: http://www.belzec.pl/index.php? ksiegagosci,0,0,pl (accessed: 1 May, 2016).

${ }^{13}$ See Bolesławiec gmina service [online]. Available at: www.boleslawiec.net.pl (accessed: 1 May, 2016).
} 
The published content was also analyzed. The observation allowed the categorization of the posts into four types:

- invitations - announcements of cultural events, designed to encourage participation in a local dance, concert, performance, etc.

- information - about local government tenders, new services of the office, etc.

- $\quad$ provocative posts - having their content designed to provoke users to interact by liking, entering a comment or sharing the post

- $\quad$ involving posts - urging the taking of action in the real world, e.g. giving donations for a commendable purpose and taking part in charity actions.

The results showed that the rural local governments had published the least number of posts (see Table 3). However, the increased activity showed those with a higher rate, that is gminas with less inhabitants who "liked" the official profile of their local government (author's note).

Table 3

\section{The results of activity of selected rural gminas in February 2017}

\begin{tabular}{|c|c|c|c|c|c|c|}
\hline $\begin{array}{c}\text { GMINA } \\
\text { (indicator) }\end{array}$ & Category & Posts & Likes & Comments & Shares & SUM/REACTION \\
\hline \multirow{5}{*}{$\begin{array}{l}\text { Dąbrowa } \\
\text { Zielona } \\
(24.49)\end{array}$} & Invitations & 1 & 2 & 0 & 0 & 2 \\
\hline & Information & 8 & 27 & 0 & 0 & 27 \\
\hline & Provocative & 0 & 0 & 0 & 0 & 0 \\
\hline & Involving & 0 & 0 & 0 & 0 & 0 \\
\hline & SUM & 9 & 29 & 0 & 0 & 29 \\
\hline \multirow{5}{*}{$\begin{array}{l}\text { Babice } \\
(10.83)\end{array}$} & Invitations & 0 & 0 & 0 & 0 & 0 \\
\hline & Information & 0 & 0 & 0 & 0 & 0 \\
\hline & Provocative & 0 & 0 & 0 & 0 & 0 \\
\hline & Involving & 0 & 0 & 0 & 0 & 0 \\
\hline & SUM & $\mathbf{0}$ & 0 & $\mathbf{0}$ & 0 & 0 \\
\hline \multirow{5}{*}{$\begin{array}{l}\text { Bobrowo } \\
(5.74)\end{array}$} & Invitations & 0 & 0 & 0 & 0 & 0 \\
\hline & Information & 1 & 10 & 0 & 1 & 11 \\
\hline & Provocative & 0 & 0 & 0 & 0 & 0 \\
\hline & Involving & 0 & 0 & 0 & 0 & 0 \\
\hline & SUM & 1 & 10 & 0 & 1 & 11 \\
\hline
\end{tabular}

Source: Author's research

In urban-rural gminas a similar tendency appeared (see Table 4). However, there is a significant difference in the activity of profile administrators - they published more posts in each of the indicated categories. 
Table 4

\section{The results of activity of selected urban-rural gminas in February 2017}

\begin{tabular}{|c|c|c|c|c|c|c|}
\hline $\begin{array}{l}\text { GMINA } \\
\text { (indicator) }\end{array}$ & Category & Posts & Likes & Comments & Shares & SUM/REACTION \\
\hline \multirow{5}{*}{$\begin{array}{l}\text { Grodzisk wlk. } \\
(15.18)\end{array}$} & Invitations & 9 & 32 & 0 & 13 & 45 \\
\hline & Information & 7 & 54 & 6 & 12 & 72 \\
\hline & Provocative & 0 & 0 & 0 & 0 & 0 \\
\hline & Involving & 4 & 17 & 1 & 5 & 23 \\
\hline & SUM & 20 & 103 & 7 & 30 & 140 \\
\hline \multirow{5}{*}{$\begin{array}{l}\text { Bystrzyca kłodzka } \\
(9.37)\end{array}$} & Invitations & 11 & 73 & 0 & 0 & 73 \\
\hline & Information & 17 & 226 & 8 & 14 & 248 \\
\hline & Provocative & 0 & 0 & 0 & 0 & 0 \\
\hline & Involving & 1 & 12 & 0 & 2 & 14 \\
\hline & SUM & 29 & 311 & 8 & 16 & 335 \\
\hline \multirow{5}{*}{$\begin{array}{l}\text { Kargowa } \\
(4.58)\end{array}$} & Invitations & 0 & 0 & 0 & 0 & 0 \\
\hline & Information & 1 & 0 & 0 & 0 & 0 \\
\hline & Provocative & 0 & 0 & 0 & 0 & 0 \\
\hline & Involving & 0 & 0 & 0 & 0 & 0 \\
\hline & SUM & 1 & $\mathbf{0}$ & 0 & 0 & $\mathbf{0}$ \\
\hline
\end{tabular}

Source: Author's research.

In both types of gminas, the message on invitations and information without encouraging one to act in a provoking or involving way was dominant.

\section{Conclusions}

The results shown in the article confirm the hypothesis, but it should be noted that the pace of adapting to the requirements of the younger generation is slow. The generation of «digital natives» - «generation Y» - is looking for information on the web and needs tools that allow easy and quick access. Information sections in the services of both types of gminas are now common, but limited access to Rodzina 500 Plus data proved to be troublesome and concerns young people

The internet is a dynamic environment and the introduction of modern tools can be very low-cost or even no-cost, and do not require exceptional computer skills. Hence, rare occurrences such as RSS feeds or newsletters can affect the reception of the content by «digital natives». The increased interest of gminas in RSS feeds and a decline in the popularity of newsletters can be interpreted by learning technology and Polish law. RSS distribution channels are fully automated. For their subscription it is not necessary to give your email data 
or personal information. It is sufficient that the recipient installs a special reader, while receiving a newsletter involves the requirement of giving your email address and putting it into a database of administrator website. The subscriber is frequently asked to authorize the entry on the mailing list, so you must take additional action which may affect the comfort of the use of the service. Notice should also be taken of the relation to Polish rules on the collection of personal data. In accordance with Generalny Inspektorat Danych Osobowych (GIODO; Bureau of the Inspector General for the Protection of Personal Data) interpretation of the article on creating personal databases, site administrators form a data collection by allowing users to make a subscription. The collector of this kind of information is required to report the collection to the Inspector General. ${ }^{14}$ It is necessary for the owners of local government services to apply the appropriate security to protect the created database and collected information about subscribers.

The research showed the dynamic growth in the number of gminas present on social networks. This is clearly including giving up on the use of the discussion forums. Analyzing the changes in the ways of communication, social networking sites have taken over the role of the forums. Discussion forums require the involvement of a moderator who organizes and disciplines the discussants. The mechanism of action on social networks eliminates the additional administrative duties and facilitates the verification and identification of the participants in the discussion (comments), plus the sharing of information (shares) or «liking» (likes). This can affect the network and limit the phenomenon of online hate speech or the use of vulgar language, which is much more difficult to control in discussion forums.

Despite the popularity of social networking sites, reviews from officials about «the lack of interest from the local community» and the "existing unofficial profiles of local governments» were surprising. The former is contrary to the data on the development of social networks. The latter opinion allows local governments to put the communication channel in the hands of random people, thus losing control of it and failing to lead their own information policy. These reviews have been confirmed in a study of published posts. Messages not involving the recipient and, in the vast majority, of little importance were dominant. This kind of content is negligible, particularly if their authors were officials of rural local governments.

The local government authorities should pay more attention to the popularity of such sites as Facebook.com or YouTube.com - new channels that allow not only a simple unilateral communication, but multilateral interaction primarily with the generation of "digital natives" - "generation Y". Increased activity on social networking sites could significantly improve public governance in Polish rural and urban-rural gminas.

\footnotetext{
${ }^{14}$ Czy należy zgłosić do rejestracji Generalnemu Inspektorowi Ochrony Danych Osobowych zbiór danych osób zamawiających usługę newsletter (Whether to report to the Bureau of the Inspector General for the Protection of Personal Data the data set of people contracting newsletter). Available at: http://www.giodo. gov.pl/330/id_art/3529/j/pl (accessed: February 1, 2017).
} 


\section{REFERENCES}

1. Castells, M. (2007). Communication, Power and Counter-power in the Network Society. International Journal of Communication, no 1, pp. 238-266.

2. Demchak, C.C, Friis, C. \& La Porte, T.M. (2000). Webbing governance: National differences in constructing the public face. In: G.D. Garson (Ed.). Handbook of Public Information Systems. New York: Marcel Dekker.

3. Diagnoza społeczna 2015. Warunki i jakość życia Polaków. Raport, ed. Czapiński J. Panek T. Warszawa: Rada Monitoringu Społecznego.

4. Dickinson, H. (2016). From New Public Management to New Public Governance: The implications for a 'new public service'. In: Butcher, J \& Gilchrist, D. The Three Sector Solution: Delivering Public Policy in Collaboration With Not-for-Profits and Business. Canberra: ANU Press.

5. E-administracja w oczach internautów 2013. Available at: https://mac.gov.pl/files/raport e-administracja_w_oczach_internautow_2013.pdf (accessed: 1 February, 2017).

6. E-administracja w oczach internautów 2016. Available at: https://mc.gov.pl/files/raport_pbs_ mc_e_administracja_12.09.2016.pdf (accessed: 1 February, 2017).

7. Howe, N. \& Strauss, W. (2000). Millennials Rising: The Next Great Generation. Vintage Books.

8. Advertising Age (1993). Editorial, Generation Y. August 30, vol. 64, no 36, p. 16.

9. Kowalik, K. (2015). Dzieci na cyfrowym "gigancie", czyli co digital immigrants wiedzą, a czego nie wiedzą o digital natives. Badania dzieci klas 1-6 i ich rodziców [Kids on the Digital «Escape», What Digital Immigrants Know and What They do not Know about Digital Natives. Studies of Children in Grades 1-6 and Their Parents]. In: Gackowski T. (ed.). Mediamorfozy, Media poczatku XXI wieku, vol. 27, Warszawa: Oficyna Wydawnicza Aspra-JR, 2015.

10. Kowalik, K. (2018). “Dystrybucja emocji” jako forma w komunikacji samorządów lokalnych w serwisie Facebook.com. Próba kategoryzacji przekazu w kontekście public relations ["Distribution of Emotions" as a Form of Communication of Local Governments on Facebook.Com. An Attempt to Categorize the Message in the Context of Public Relations]. Studia Medioznawcze, vol. 74, no 3. Available at: DOI /10.33077/uw.24511617. ms.2018.3.54 (accessed: 1 February, 2017).

11. McQuaid, R.W. (2010). Theory of Organisational Partnerships - partnership advantages, disadvantages and success factors. In: S.P. Osborne (ed.). The New Public Governance: Critical Perspectives and Future Directions. London: Routledge.

12. Mergel, I. (2010). Government 2.0 Revisited: Social Media Strategies in the Public Sector, PA Times. American Society for Public Administration, vol. 33, no 3.

13. Mysior, R. (2014). Dwa światy - cyfrowi tubylcy, cyfrowi imigranci. Cz. I. «Remedium» 7-8. Available at: http://www.uzaleznieniabehawioralne.pl/strefa-profesjonalistow/dwa-swiatycyfrowi-tubylcy-cyfrowi-imigranci-cz-i/ (accessed: 1 February, 2017).

14. OECD 2003. The E-Government Imperative: Main findings OECD, Paris.

15. Osborne, S. P. (2006). The New Public Governance? Public Management Review, vol. 8, no 3. Available at: DOI: doi.org/10.1080/14719030600853022 (accessed: 1 February, 2017). 
16. Osborne, S. P. (2010). The New Public Governance? New York: Routledge.

17. O'Reilly, T. (2009). What is Web 2.0. Design Patterns and Business Models for the Next Generation of Software. Available at: http://www.oreilly.com/pub/a/web2/archive/whatis-web-20.html?page=1 (accessed: 1 February, 2017).

18. Pollitt, C. \& Bouckaert, G. (2011). Public Management Reform. A Comparative Analysis: New Public Management, Governance, and the Neo-Weberian State. Oxford: Oxford University Press.

19. Polskie Badania Internetu (2016). Available at: pbi.org.pl/wp-content/uploads/2016/12/ 02-RAPORT-Wiadomości-lokalne-2016.pdf (accessed: 1 February, 2017).

20. Prensky, M. (2001). Digital Natives, Digital Immigrants. Available at: http://www.marcprensky. com/writing/Prensky\%20-\%20Digital\%20Natives,\%20Digital\%20Immigrants\%20-\%20Part1. pdf (accessed: 1 February, 2017).

21. Tapscott, D. (2009). Grown up Digital. New York: McGraw Hill.

22. Wawer, M. (2013). Edukacja pracowników pokolenia Y - nowe potrzeby i rozwiązania. Uniwersytet Rzeszowski, Edukacja - Technika - Informatyka, vol. I, no 4.

23. Wearesocial.com. Digital in 2017: Eastern. Available at: https://www.slideshare.net/wearesocialsg/ digital-in-2017-eastern-europe (accessed: 1 February, 2017).

24. Wieczorek, M. (2017). Facebook w Polsce - podsumowanie 2016 r. Available at: https://www. sotrender.com/blog/pl/2017/01/facebook-w-polsce-podsumowanie-2016-r-infografika/ (accessed: 1 February, 2017).

25. Wrzesień, W. (2007). Czy pokoleniowość nam się przydarzy? Kilka uwag o współczesnej polskiej młodzieży. Nauka, no 3, p. 135. 